\author{
Ewa Żmudzin-Zielińska \\ Jagiellonian University, \\ ul. Gołębia 24, 31-007 Cracow, Poland
}

\title{
Translating conversational humour. The case study of House M.D.
}

\section{Introduction}

The complex phenomenon of humour has never ceased to inspire interest of philosophers starting from Plato, Kant and Henri Bergson and has traditionally been considered to be a problematic area of Translation Studies. This question becomes even thornier when we examine it in the context of audiovisual translation, mainly because of the technical constraints imposed by this type of translation. There have been numerous studies dedicated to humour translation for audiovisual purposes carried out in recent years. Nevertheless, there is still a wide expanse of unexplored land to discover.

First of all, it is not very common that the reflection on Audiovisual Translation involves the subject of translating for voiceover purposes - question which seems especially interesting in Poland where this audiovisual translation mode predominates in television translation.

Secondly, the research covers humour translation for audiovisual purposes from the point of view which has not been explored in the 
Translating conversational humour. The case study of House M.D. 111

previous studies. The vast majority of research dedicated to this particular field focused on productions where humour was its predominant feature and as such should have been treated by translator, for example comedies or animated films. Meanwhile, the corpus of this study consists of extracts from TV series which, although include significant volume of humour, are not humorous productions par excellence.

The article focuses on conversational humour which embodies various manifestations of humour in a dialogue within the realm of audiovisual translation. An excellent example of audiovisual production which contained numerous humorous scenes but at the same time was not a comedy was the American TV series House M.D which was selected for the purpose of this research.

The main objective of the analysis was to identify and describe the principal tendencies of translating conversational humour in selected episodes of TV series House M.D. We compared the source text in English with two different target texts:

1. Spanish target text designed for dubbing mode prepared by the dubbing studio Abaira. The preparation of dubbing was directed by the dubbing director, Pablo Adán. The source text has been translated into Spanish by Francisco Vara.

2. Polish target text designed for voice-over mode prepared by Marek Nowiński for public broadcaster TVP and read by Maciej Gudowski.

The analysis involved different translation modes (dubbing and voice-over) and different target languages (Spanish and Polish). It was based on 122 humorous scenes from the following 6 episodes of medical drama House M.D:

1. Season I, Episode 8: POISON, 20 scenes

2. Season I, Episode 17: ROLE MODEL, 20 scenes

3. Season II, Episode 17: ALL IN, 17 scenes

4. Season II, Episode 19: HOUSE VS. GOD, 23 scenes

5. Season III, Episode 4: LINES IN THE SAND, 21 scenes

6. Season III, Episode 10: MERRY LITTLE CHRISTMAS, 21 scenes 
The last stage of the analysis consisted of responding to numerous questions which always appear in the context of humour translation. First of all, we tried to determine whether conversational humour travels across different cultures and languages. Then, we tried to establish whether the humour in the source text was translated or rather adapted to the target languages. The final point was to address the problem of disappearance of humour elements in the target texts and to identify the reasons behind it.

The results of the research have proved that the responses are not invariably unequivocal. According to Tabakowska (2008: 17) Translation Studies is a field where we should rather speak about case studies instead of general rules which should be applied regardless of the circumstances. Nevertheless, a collection of case studies builds up diverse image of Translation Studies. This analysis was undertaken in order to contribute to creation of this image.

\section{Methodological frames}

The beacon of this study is conversational humour. The term was introduced by Neal R. Norrick and developed further by Marta Dynel. Dynel (2009: 1284) distinguished two types of verbal humour: jokes and conversational humour and focused her attention on the second category.

According to Dynel (ibid. 1285) conversational humour is "an umbrella term which covers a variety of semantic and pragmatic types of humour which are present in everyday as well as in fictional communication". The category of conversational humour embraces single-word lexemes as well as more complex units called phrasemes. Those humorous segments go beyond the limits of linguistic convention as the vast majority of them are neologisms or more complex units which manifest humour potential. For example, the below extract which originates from the TV series House M.D. weaves a cultural reference to a popular song into a medical diagnosis.

FOREMAN: Our kid's been tripping on Lucy in the Sky with Cubic Zirconium; explains the pleural effusion, the heart arrhythmias. 
The second part of the methodology applied was designed by Patrick Zabalbaescoa. According to Zabalbaescoa (2001: 258) there are seven joke types: international joke, national culture and institution joke, national sense of humour joke, language-dependent joke, visual joke, paralinguistic joke and complex joke.

Before we comment on each of the joke type specified by Zabalbaescoa we would like to clarify one aspect related to terminology. Although Zabalbaescoa speaks about joke types we cannot narrow down our scope only to joke study. Conversational humour stays outside this limited category and, therefore, in view of terminological accuracy, we used term humour instead of joke.

Moreover, it should also be underlined that Zabalbaescoa's taxonomy lacks common classification criterion. On the one hand, the first three categories (international joke, national culture and institution joke, national sense of humour joke) cover humour whose potential consists of jocular subject. Therefore, the applied classification criterion was the subject. On the other hand, in case of language-dependent category, visual category and paralinguistic category the applied criterion was communication channel which would be acoustic in case of language-dependent and paralinguistic category and visual in case of visual category. Undoubtedly, Zabalbaescoa's humour typology has its weak points. At the same time, however, it manages to embrace complex field of humour translation in audiovisual context into well-defined frames.

Let us now outline and provide description of each of the categories defined by Zabalbaescoa.

1. International joke does not use cultural references and does not depend on linguistic features of the original utterance.

2. National culture and institution joke builds up its humour effect on cultural or national background.

3. National sense of humour joke consists of amusing subject typical for and well known in some countries or communities.

4. Language-dependent joke depends on features of natural language. 
5. Visual joke is where the humour derives only from what the audience sees on the screen.

6. Paralinguistic joke is based on non verbal manifestations such as accent, pronunciation, tone of voice.

7. Complex joke combines any two or more of the above mentioned types of joke.

Let us now describe how the methodology tools were used in order to carry out the analysis. The total number of 122 scenes were examined in order to identify the source of humour in the target text and possible translation problems. Once the humour source and possible translation problems were identified we focused on target texts: Spanish and Polish.

The complete corpus of scenes was divided into two categories. The first included conversational turns which were neither affected by quantitative content modification nor qualitative humour modifications. The second category embraced those scenes which were affected by quantitative and qualitative modifications. Each modification was examined separately, both its origin (if it was caused by cultural or linguistic restrictions or if it was required because of the translation mode) and its character (neutralization or omission, adaptation, compensation in order to preserve the humorous effect). Furthermore, the results were divided into four groups:

1. Scenes which suffered total loss of humour

\begin{tabular}{|l|c|c|}
\hline \multicolumn{1}{|c|}{ SOURCE TEXT } & SPANISH DUBBING & POLISH VOICE-OVER \\
\hline $\begin{array}{l}\text { Good coffee. Cheaper } \\
\text { than Prozac. }\end{array}$ & - & - \\
\hline
\end{tabular}

The source of humour in the above example is a witticism which appears on the TV screen only in graphic form as an inscription on the coffee machine. According to conversational humour taxonomy, witticisms are "similar to non-humorous sayings and proverbs in the sense that they are communicative entities comprehensible even in 
isolation" (Ibid.: 1287). The inscription does not form part of a dialogue. As it appears only in graphic form it falls into category of visual humour and therefore, should be translated in form of a subtitle. There are no cultural references that would disturb humour comprehension. Although there has been no possible translation problems identified, the inscription was neither translated into Spanish nor into Polish. The humour loss is complete as the humour potential was ignored by both translators.

2. Scenes which suffered partial loss of humour

\begin{tabular}{|c|c|c|}
\hline $\begin{array}{l}\text { SOURCE } \\
\text { TEXT }\end{array}$ & SPANISH DUBBING & $\begin{array}{l}\text { POLISH } \\
\text { VOICE OVER }\end{array}$ \\
\hline $\begin{array}{l}\text { WILSON: It's } \\
\text { toxoplasmosis. } \\
\text { FOREMAN: You're sure? } \\
\text { HOUSE: Which means the } \\
\text { Great Black Hope has full- } \\
\text { blown AIDS. They're going } \\
\text { to love that in Dubuque. }\end{array}$ & $\begin{array}{l}\text { WILSON: Es } \\
\text { toxoplasmosis. } \\
\text { FOREMAN: ¿Seguro? } \\
\text { HOUSE: La gran } \\
\text { esperanza negra me } \\
\text { parece que tiene SIDA. } \\
\text { Qué alegría para su } \\
\text { partido. }\end{array}$ & $\begin{array}{l}\text { WILSON: } \\
\text { Toksoplazmoza. } \\
\text { FOREMAN: Na pewno? } \\
\text { HOUSE: Czyli wielka } \\
\text { nadzieja czarnych ma } \\
\text { zaawansowane AIDS. Ku } \\
\text { Klux Klan oszaleje z } \\
\text { radości. }\end{array}$ \\
\hline
\end{tabular}

The source of humour in the above example is a retort which consists of witty and humorous reply.

Firstly, we can identify syntactic parallelism in the source text which consists of repetition of similar phrasal structures. It is not accidental that the subject and the direct object consist of three words (Great Black Hope/full-blown AIDS). Its main function is to create specific rhythm of the phrase.

Secondly, humour of this scene is based on a cultural reference typical of American reality where racial issues are invariably present in the public debate. "Dubuque" is a town situated in the Iowa State which witnessed racial agitation that attracted public attention during the early ' 90 . The humour is produced by a combination of cultural and institutional element, national sense of humour element and 
linguistic humour. We can risk a statement that the translation of all three elements would constitute a great challenge for the translator.

In the Spanish target text the rhythm of the original sentence was not reflected. Moreover, the translator has misunderstood the significance of the cultural reference "Dubuque". The senator who is the recipient of the ironic comment is black and he is a democrat whereas the original utterance refers to a place commonly identified with racial aversion towards the black community. Although the irony is present in the Spanish target text, the omission of the original cultural reference and rhythm contributes to the fact the scene fell into the category of partial humour loss.

On the other hand, the cultural reference in the Polish target text was substituted by a similar one related to a history of racial conflicts in the United States ("Ku Klux Klan") which seems to be more evident for the Polish audience than the original reference ("Dubuque") and therefore is a positive modification of the source text contributing to humour preservation. The linguistic aspect of the original text (parallelism) disappears in the target text. Due to this omission the scene fell into the category of partial humour loss.

3. Scenes which preserved humour but suffered qualitative or quantitative modification.

\begin{tabular}{|l|l|l|}
\hline SOURCE TEXT & SPANISH DUBBING & POLISH VOICE-OVER \\
\hline WILSON: "The healer & WILSON: "El sanador & WILSON: “Uzdrowicielu o \\
with his magic powers. & con su mágico poder! & tajemnej mocy, chciałabym \\
I could rub his gentle & Podríaacariciar su dulce & Cię pieścić pół nocy. Masz \\
brow for hours. His & frente con placer. Su & boski tors i wydatną szczękę. \\
manly chest, his stubble & pecho viril, su barba. & Na twój widok nogi... \\
jaw. Everything about & Todo en él me & HOUSE: Psychiatria wyżej. \\
him leaves me & embarga emoción...". & WILSON: ...mam miękkie. \\
raw...” & HOUSE: Psiquiatría es & Doktorze House, twe sławne \\
HOUSE: Psych ward's & arriba. & imię zawróci w głowie \\
upstairs. & WILSON: ...y te digo. & każdej dziewczynie. \\
WILSON: "... with & Oh, Doctor, que tu mero & \\
joy. O House, your & nombre me dice con ardor & \\
very name will never & que eres mi hombre. & \\
\hline
\end{tabular}


Translating conversational humour. The case study of House M.D. 117

leave this girl the

same."

We can classify the above passage as an example of conversational humour category called teasing. Teasing is defined as an exchange of humorous utterances "performing a variety of pragmatic functions, such as mock challenges, threats or imitations."(Dynel 2009: 1293). The humour of the scene is based on its linguistic aspect as the source text is a poem. The humour of the scene falls into the linguistic category and the biggest translation problem consist of reflecting the rhyme of the original text. In the Spanish and Polish target texts the translators introduced slight changes to the original text in order to preserve the rhyme of the source text. However, the overall overtone of the source text has been preserved.

4. Scenes where we can observe humour increase in the target texts.

\begin{tabular}{|c|c|c|}
\hline SOURCE TEXT & SPANISH DUBBING & POLISH VOICE-OVER \\
\hline $\begin{array}{l}\text { PATIENT: In Iceland, the } \\
\text { age of consent is } 14 \text {. } \\
\text { HOUSE: I'm surprised } \\
\text { that tourism isn't a bigger } \\
\text { industry up there. }\end{array}$ & $\begin{array}{l}\text { PACIENTE: En Islandia, } \\
\text { la edad legal son los } 14 . \\
\text { HOUSE: Me sorprende } \\
\text { que el turismo no los } \\
\text { desborde por aquellos } \\
\text { lares. }\end{array}$ & $\begin{array}{l}\text { PACJENTKA: Na } \\
\text { Islandii wystarczy mieć } 14 \\
\text { lat. } \\
\text { HOUSE: Dziwię się, że } \\
\text { nie jest Mekką turystów. }\end{array}$ \\
\hline
\end{tabular}

According to the conversational humour typology, the source of humour in the above passage is an ironic retort made by House in reply to a sexual offer.

Both Spanish and Polish target texts are examples of humour increase. In Spanish, the original retort acquires new dimension as a result of the word "lar" which implies poetic shade of meaning which is absent in the source text. In Polish, we can observe an introduction of cultural reference present in the word "Mekka" which has double meaning in Polish. The capitalized word "Mecca" relates to the holiest city in the religion of Islam and its religious connotation is obvious. 
The second, figurative meaning relates to a place which is often visited, because it is famous for something. This semantic ambiguity contributes to the humour increase in the Polish target text.

3. Results of the analysis

3.1. Analysis of the source text

The below graph shows the distribution of humour elements in total of 122 scenes analyzed throughout the research.

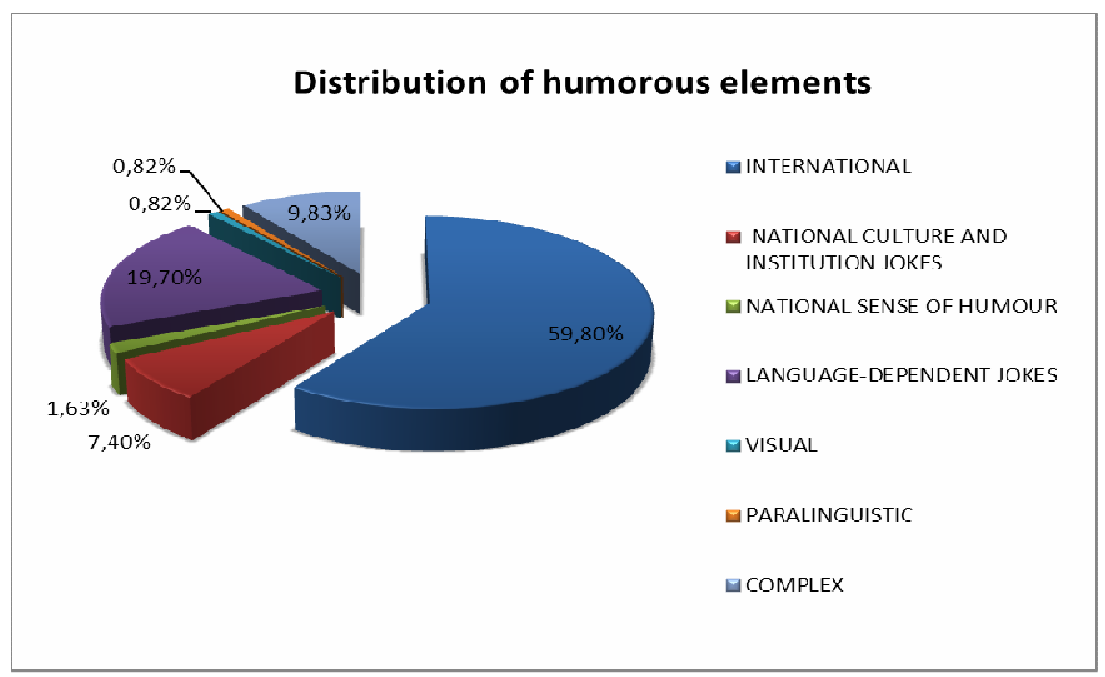

Figure 1. Distribution of humorous elements.

The number of scenes which represented the category of international type of humour meaningfully prevails as approximately $60 \%$ of the total number of scenes analyzed belong to this category.

The second category with the highest volume of scenes is language-dependent humour. The number of scenes which include language based humorous utterances reached approximately 20\% (24 out of 122 belong to language-dependent category). 
Furthermore, the volume of scenes which owe their humorous effect to cultural elements is meaningful (9.03\%) as humour of 11 out of 122 scenes was based on cultural references.

It is quite surprising that the volume of paralinguistic and visual humour scenes does not exceed $1.6 \%$. It would be justified to state that their presence is quite insignificant. However, many scenes which belong to the complex category contain precisely paralinguistic elements so their shortage is only apparent. The number of complex scenes which create their humorous effect by combining two or more elements reached up to $9.83 \%$.

3.2. Analysis of the target texts: Spanish and Polish

The results of the analysis of both target texts show that $71 \%$ out of a total number of scenes in Spanish were not affected by any changes. In Polish, it was 53\% of the scenes that did not suffer any modifications.

In the Spanish target text only 35 scenes out of 122 suffered modifications during translation.

The majority of modifications in Spanish were of qualitative nature meaning that the changes introduced affected the quality of humour in the target text due to omitting national-cultural, language dependent and paralinguistic humorous elements. The total or partial humour loss was observed in case of 20 scenes. In case of 6 scenes the loss of humour was complete whereas 14 scenes experienced partial humour loss. Only 1 scene has acquired new sense in its target text which contributed to humour increase. Up to 15 humour scenes suffered qualitative or quantitative modifications but at the same time managed to preserve humour despite the changes in the content.

It was quite unexpected that the number of scenes which experienced modifications introduced because of the dubbing synchrony requirements was very limited. The majority of modifications were introduced in order to make the target text more intelligible for the target audience, for example through adaptation of cultural references or substitution of original puzzles or word games 
which explored possibilities of the source language by different ones in the target language.

To sum up, the research showed that in case of humour translation into Spanish there has been a decrease of humorous elements by $16 \%$ as 20 out of 122 scenes suffered total or partial humour loss.

In the Polish target text prepared for voice-over mode 58 out of 122 humorous scenes suffered modifications. The number of modified scenes in Polish exceeds the number of such scenes in Spanish target text which contradicts common belief that the dubbing mode requires more content modifications due to synchrony requirements. 13 scenes suffered total loss of humour whereas 18 suffered partial reduction of humour in the target text. Therefore, 31 scenes which constitute approximately half of the total volume of scenes which were modified experienced quantitative or qualitative modifications which resulted in a humour decrease. Humour elements which suffered modifications of qualitative nature belong to language dependent and culturalinstitutional categories whereas in case of quantitative changes we identified two which correspond to the international humour category.

In case of Polish target text we can observe the decrease of humour elements by $25 \%$ as 31 scenes out of 122 experienced total or partial humour loss. We can speak of humour increase in case of 3 scenes in the Polish target text. The group of scenes which suffered modifications but managed to preserve humour consists of 24 scenes. The majority of modifications consisted of reducing Polish target text due to voice-over requirements.

The below extract is an example of qualitative modification both in Spanish and Polish which contributed to total humour loss in both language versions.

\begin{tabular}{|l|l|l|}
\hline SOURCE TEXT & SPANISH DUBBING & POLISH VOICE-OVER \\
\hline $\begin{array}{l}\text { CHASE: I'm going to be } \\
\text { here all night. }\end{array}$ & $\begin{array}{l}\text { CHASE: Estaré aquí toda } \\
\text { la noche. } \\
\text { me too-er. }\end{array}$ & $\begin{array}{l}\text { CHASE: Spędzę tu całą } \\
\text { noc. }\end{array}$ \\
HOUSE: Todos son unos & $\begin{array}{l}\text { HOUSE: Zamiast } \\
\text { zrzędzić, bierz się do } \\
\text { lloboty. }\end{array}$ \\
\hline
\end{tabular}


The source of humour in the above passage is language dependent and it is based on the rhyme between the word "doer" derived from the verb "do" and the word "too-er" derived from the expression "me too". Neither Spanish nor Polish language version reflects the original feature of the source language, the fact which contributes to the total humour loss in both language versions.

\section{Conclusion}

Although translating humour is considered to be a problematic aspect of translation, we identified a clear trend to maintain conversational humour in both target texts.

Moreover, we should point out the significance of intercultural dimension of the examined source text of House M.D. The fact that $15 \%$ of all analyzed scenes in the original text were marked by cultural or national references proves the prevailing rule that the translator, apart from being bilingual, additionally should be bicultural. It is the ability of high importance in the context of humour translation as it enables to identify humour, question not always evident. In the category of scenes which suffered qualitative humour loss, those which were based on the cultural references predominated. It is not rare that they disappear completely in the target texts or are neutralized at the expense of their cultural aspect. Therefore, it would be justified to make a statement that cultural elements constitute an obstacle which very often seems insurmountable in case of humour translation.

Let us now focus on those examples based on cultural references where humour traveled successfully. We can identify two different approaches in both examined target texts.

In case of the Spanish version we can speak of domesticating approach as in majority of the cases translator decided to substitute those elements which turned out to be unintelligible for the Spanish audience and to introduce humour elements typical of the Spanish culture. As a result of this solution references to the North American culture which contributed to the humour creation in the source text disappear in the Spanish target text but at the same time humour was 
maintained. Moreover, it was quite frequent that the culturalinstitutional aspect of humour was deprived of its cultural dimension and neutralized.

The below extract shows how cultural reference present in the source text referring to iconic T-shirts popular in the ' 80 in the English-speaking world was substituted in the Spanish version by different cultural reference of international recognition (Donald Duck).

\begin{tabular}{|c|c|}
\hline SOURCE TEXT & SPANISH DUBBING \\
\hline $\begin{array}{l}\text { HOUSE: While you were all wearing } \\
\text { your "Frankie says relax" t-shirts, I was } \\
\text { treating a } 73 \text {-year-old woman who went } \\
\text { through this progression of symptoms. } \\
\text { The last of which was... death. } \\
\text { In case any of you missed } \\
\text { that class in med school, } \\
\text { that one's untreatable. }\end{array}$ & $\begin{array}{l}\text { HOUSE: Cuando vosotros aún } \\
\text { llevábais camisetas del Pato Donald, yo } \\
\text { traté a una mujer de } 73 \text { años que tuvo } \\
\text { esta progresión de síntomas. El último } \\
\text { de los cuales fue una muerte. Y por si } \\
\text { no fuiste ese día a la Facultad, no tiene } \\
\text { tratamiento. }\end{array}$ \\
\hline
\end{tabular}

In case of the Polish target text we identified foreignizing approach which manifests itself by maintaining cultural references completely incomprehensible for the Polish audience. This approach is clearly visible in the below extract. In the source text appears a cultural reference to one of the protagonists of a baseball poem "Casey at the Bat" written in 1888 by Ernest Thayer. It has been maintained in the Polish target text, even though its humorous effect will remain unnoticed by the Polish audience.

\begin{tabular}{|l|l|}
\hline SOURCE TEXT & SPANISH DUBBING \\
\hline HOUSE: Mighty Casey's & HOUSE: Ostatnia próba wielkiego \\
down to his last strike. & Caseya. \\
$\begin{array}{l}\text { FOREMAN: } 21 \text { Mighty Casey struck } \\
\text { out. }\end{array}$ & $\begin{array}{l}\text { FOREMAN: Nie trafił w piłkę. } \\
\text { HOUSE: Wielkie dzięki. Chciałem to } \\
\begin{array}{l}\text { HOUSE: Thanks a lot. Wanted to read } \\
\text { that. }\end{array}\end{array}$ \\
\hline
\end{tabular}


It is just one example which proves the strategy to adapt foreign cultural references to more familiar ones that would be intelligible for a Polish spectator has not been applied by the Polish translator.

The second category of scenes which entailed translation problems embraces language dependent humour scenes. Humorous potential was created by exploring features of the source language in case of $26 \%$ of all scenes. It should be emphasized that this aspect of humour translation of House M.D. constituted a great challenge for the translators as it was based on a deliberate use of particular language styles and register juggling. Our analysis shows that majority of language dependent scenes retains humour in the target text $(70 \%$ of the scenes in the Spanish target text whereas in case of the Polish target text the number reached 62\%). Both in the Spanish and Polish target text the most frequent applied strategy to retain language dependent humour was adaptation.

There was one example of humour loss which undoubtedly could have been avoided. It was the case of the visual humour example which appeared on the screen only in graphic form. The humorous inscription was ignored both by Spanish and Polish translator and even though we should point out it was an individual case it is the case of humour loss which was unnecessary and happened independently of the features of the source text. It is an example of how translator's passive attitude may contribute to humour loss. Despite the fact that the source text is not a humorous production per se, humour is one of its features. Maintaining it in the target language should be a part of translator's strategy.

\section{Bibliography}

Agost, R., 1999, Traducción y doblaje: palabras, voces e imágenes, Barcelona: Ariel.

Chaume Varela, F., 2000, Aspectos profesionales de la traducción audiovisual In: D. Kelly (eds.), La profesión del traductor, Granada: Comares, pp. 47-83.

Chiaro, D., Verbally expressed humour on screen: reflections on translation and reception. Retrieved $16^{\text {th }}$ of April 2014 from http://www.jostrans.org/issue06/art_chiaro.php.

Chiaro, D., 1992, Language of Jokes: Analyzing Verbal Play, London: Routledge. 
Chłopicki, W., 1995, O humorze poważnie, Kraków: PAN.

Díaz Cintas, J., 2003, Teoría y práctica de la subtitulación: inglés/español, Barcelona: Ariel.

Dynel, M., 2007, Nie wszystkie tłumaczenia zostały stworzone równymi. Techniki tłumaczenia elementów kulturowych na przykładzie humoru konwersacyjnego w języku angielskim i polskim., In: M. Piotrowska (ed.), Język a komunikacja 18: Wspótczesne kierunki analiz przektadowych, Kraków: Tertium, pp. 165-175.

Díaz Cintas, J., 2003, Teoría y práctica de la subtitulación: inglés/español, Barcelona: Ariel.

Glaser, G., 1991, Why Marilyn Monroe is a Polish baritone? Retrieved $12^{\text {th }}$ of December 2013 from http://www.nytimes.com/1991/02/24/movies/film-whymarilyn-monroe-is-a-polish-baritone.html.

Gumul, E., 2004, O grze słów w przekładach list dialogowych Latajacego Cyrku Monthy Pythona. In: P. Fast (ed.), Przektad a kultura popularna, Katowice: Wydawnictwo Naukowe, pp. 65-79.

Martínez-Bartlomé, M., 1995, La traducción del humor: las comedias inglesas en español, Oviedo: Universidad de Oviedo.

Martínez-Sierra, J. J., 2004, Estudio descriptivo y discursivo de la traducción del humor en textos audiovisuales. El caso de los Simpson. Retrieved $21^{\mathrm{st}}$ of October 2013 from http://www.tdx.cat/handle/10803/10566.

Szarkowska, A., 2009, Przekład audiowizualny w Polsce - perspektywy i wyzwania, Przektadaniec, No. 20, pp. 8-25.

Tabakowska, E., 2008, O przekładzie na przykładzie. Rozprawa tłumacza z „Europa” Normana Daviesa, Kraków: Znak.

Woźniak, M., 2009, Jak rozmawiać z kosmitami? Kilka uwag o tłumaczeniu lektorskim telewizyjnych filmów fantastyczno-naukowych (na przykładzie Star Trek), Przekładaniec, No. 20, pp. 50-88.

Zabalbaescoa Terrán, P., 2001, "La traducción del humor en textos audiovisuales". In: M. Duro (eds.), La traducción para el doblaje y para la subtitulación, Madrid: Cátedra, pp. 251-256.

Zabalbaescoa Terrán, P., 2008, "The nature of the audiovisual text and its parameters". In: J. Díaz Cintas (ed.), The Didactics of Audiovisual Translation, Amsterdam: John Benjamins Publishing Company, pp. 21-38. 